\title{
Evaluation of the Sensory Quality of Sweetened Sesame Paste (Sesamumindicum)
}

\author{
Piedad Margarita Montero-Castillo ${ }^{\# 1}$, Diofanor Acevedo-Correa ${ }^{\# 2}$, \\ Jhon Eduardo Rodríguez-Meza ${ }^{\#}$, Laury Quintero-Tapia ${ }^{\#}$, Raúl J. Martelo ${ }^{* 3}$ \\ ${ }^{\#}$ Faculty of Engineering, Food Engineering program, Research Group NUSCA, University of Cartagena \\ Av. El Consulado, St. 30 No. 48-152. Cartagena de Indias, Colombia. \\ *Faculty of Engineering, Research Group in Communications and Informatics Technologies GIMATICA. \\ University of Cartagena
}

\section{1'pmargaritamontero@hotmail.com;2'diofanor3000@gmail.com; ${ }^{3}$ rmartelog@gmail.com}

\begin{abstract}
From sesame, it is possible to obtain a creamy paste, which could represent a solution to the problem of wasteful production of this oilseed. In view of the above, the sensory quality of sweetened sesame paste formulated with added bovine blood plasma as a surfactant for possible use in confectionery was assessed in the present investigation. A completely randomized experimental design was used, under a multilevel $2 \times 2 \times 4$ factorial structure at half fraction to rule out effects of similar treatments. It was evaluated the effect of factors ( 80 and $70 \%$ sesame paste, syrup (water + sugar + glucose) at 20 and $30 \%$ and bovine blood plasma at $0.75,1.0,1.25$ and $1.5 \%$ ) on the sensory responses of the 8 formulations. The sensory evaluation of the different treatments was carried out through preference and acceptance tests; the treatment with $70 \%$ of paste, $30 \%$ syrup and $1 \%$ plasma was the most widely accepted. The best treatment was $\mathrm{T} 2$ followed by $\mathrm{T6}$. T8 showed significant differences in the parameters evaluated when compared to other treatments, and in turn had the lowest acceptance in the evaluated attributes. In general, treatments with a higher percentage of syrup had greater preference and acceptance for the same blood plasma content. In addition, $1 \%$ plasma is sufficient in the formulation of the paste, and higher concentrations make it perceptible, making the consumer reject the product.
\end{abstract}

Keyword-Sesamumindicum L., Blood Plasma, Surfactant, Sensory Analysis.

\section{INTRODUCTION}

Sesame, known in Colombia as sesame (Sesamumindicum L.) is considered a food of importance in human nutrition [1]. At present, these seeds are mainly used for the production of oils [2-10], but they can also be used for the production of oily pastes $[1,11]$ and other types of formulations [11-13].

From sesame seed it is possible to obtain a rich paste using technological processes, including conditioning, husking, roasting and milling [12]. Sesame paste has a high nutritional value, as it is rich in lipids (between $54 \%$ and $65 \%$ ), proteins (between $17 \%$ and $27 \%$ ), carbohydrates (between $6.4 \%$ and $21 \%$ ), dietary fibre (approximately 9\%), niacin (approximately $4.5 \mathrm{mg} 100 \mathrm{~g}^{-1}$ ), thiamine (approximately $1 \mathrm{mg}^{100 \mathrm{~g}^{-1}}$ ), and some

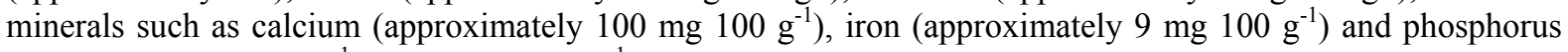

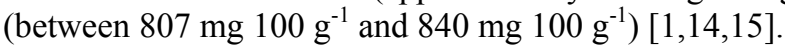

It should be highlighted that Colombia is the third largest sesame seed producer in Latin America. It is cultivated in the departments of Magdalena, Bolívar, Sucre, Córdoba and Tolima, but there are currently no production policies in place to prevent post-harvest losses and increase their added value [16]. A product derived from sesame seeds, which is highly acceptable to the Colombian population, especially on the Caribbean coast, is sesame paste [1,15], which is a nationally indigenous product produced under the name of tahini in other parts of the world[11]. As it is a product derived directly from the milling of the seed, it is used as an ingredient for creamy desserts and sauces $[1,12,14]$, so there are options to take advantage of the sesame production chain.

On the other hand, there is currently an important demand for raw materials with a high nutritional value, which contribute to providing nutritional supplements that are adequate to the population's requirements, which makes it necessary to look for low-cost alternatives to meet these requirements[17]. Among these little explored alternatives are plasmic proteins, which present favourable characteristics for their use in the food industry, among which it is worth mentioning their high nutritional value, their participation as a surfactant, foaming agent, binder and their capacity to form gels $[13,16,17]$.

In Colombia, the high production of animal blood generated in slaughtering plants in relation to low demand indicates its underutilization, which makes it an environmental problem, given that much of this by-product is dumped into water sources[13,18]. Paradoxically, this same blood can be used for human consumption, highlighting the bovine blood plasma as a by-product to be incorporated in various food matrices as a source of 
low-cost protein, since this is one of its main components, and also has functional properties for application in the food industry, which is why it is already being used in some countries [19].

On the other hand, the addition of various flavours, spicy touches, sugars and salts to the traditional sesame paste has become a traditional practice by the farmers of the Montes de María. One of the most commonly used ingredients is sucrose, which undergoes heat treatment until it is converted into a viscous fluid. In this study, a mixture of sucrose and glucose was used due to its water solubility properties. Glucose is the most abundant monosaccharide in nature, it is present in fruits such as apples, strawberries, grapes and vegetables such as onions and other products such as honey. In addition, its importance lies in the fact that it is an essential and multitransformable raw material for obtaining other products. It is an eldosa belonging to the hexose family, which is obtained from the complete and controlled hydrolysis of starch and gives rise to other sugars such as sucrose and fructose. It is an important form of carbohydrate in the metabolism of cells [20]. Therefore, the objective of the present investigation was to evaluate the sensory quality of a sweetened sesame paste formulated with added bovine blood plasma as a surfactant for possible use in baking.

\section{MATERIALS AND METHODS}

\section{A. Raw material}

Sesame (S. indicum L.), a white 70 than variety from the mountainous region of the Municipality of Córdoba, Bolívar (Colombia), was used. Lyophilized bovine blood plasma supplied by Tecnas S. A. (Medellín, Colombia) was used. The other inputs used in the formulation (sodium chloride, sucrose and glucose) were obtained from supermarkets in the city of Cartagena de Indias, Colombia.

\section{B. Technological elaboration of sesame paste}

The methodology for the production of technified sesame paste, previously reported [1,14], was used. To make the paste, $1000 \mathrm{~g}$ of sesame seeds was cleaned and husked, then immersed in $6 \mathrm{~L}$ of water at room temperature for $12 \mathrm{~h}$. The soaked seeds were squeezed and husked, then immersed for $5 \mathrm{~min}$ in a $23 \% \mathrm{w} \mathrm{w}^{-1}$ saline solution (each $1000 \mathrm{~g}$ in $8 \mathrm{~L}$ of solution). In order to separate the shells and other foreign elements, the immersion of the seeds in the saline solution was repeated three times, then taken from the surface of the solution and washed with water five times to remove the sodium chloride. Later, the seeds were squeezed to reduce their surface water content and then used for the roasting process in this study. $250 \mathrm{~g}$ of wet peeled seeds were roasted at a temperature of $140^{\circ} \mathrm{C}$ in a Challerger HE 2495 compact oven for 30 min with stirring. It was immediately balanced at room temperature to avoid overheating. The roasted seeds were ground in a Corona brand grain mill twice.

\section{Syrup elaboration}

Sugar and water in a ratio of 1:1 were used to make syrup and liquid glucose was added to $3 \%$ of the total sucrose weight. After having the syrup ready, and with the help of a D-500 - LB Pro Disperser, the sesame paste and $50 \%$ plasma were mixed for $30 \mathrm{~s}$ at $2 \mathrm{rpm}$. Afterwards, the syrup was slowly added between 2 and $4 \mathrm{rpm}$ for 2 minutes and the remaining $50 \%$ of plasma was mixed for 3 minutes, achieving a good homogenization. It is important to note that the syrup should not be hot when added to the paste, as it would facilitate the separation of oil from sesame paste.

\section{Experimental Design}

A completely randomized experimental design was used, using factors (with their respective levels): sesame paste ( $80 \%$ and $70 \%)$, syrup ( $20 \%$ and $30 \%$ ) and blood plasma of bobbin $(0.75 \% ; 1.0 \% ; 1.25 \%$ and $1.5 \%)$, for a total of 8 experimental formulations, with three replicates of each treatment, for a total of 24 experimental units. The response variables for evaluating the sensory quality were the preference and acceptance tests (general acceptability, taste, smell, texture and appearance) of the sugar paste. The formulations used shown in Table 1 were selected based on preliminary testing.

Table 1. Formulations for the sweetened sesame paste elaboration.

\begin{tabular}{|c|c|c|c|}
\hline Treatment & Sesame paste (\%) & Syrup (\%) & Plasma (\%) \\
\hline T1 & 70 & 30 & 0.75 \\
\hline T2 & 70 & 30 & 1 \\
\hline T3 & 70 & 30 & 1.25 \\
\hline T4 & 70 & 30 & 1.5 \\
\hline T5 & 80 & 20 & 0.75 \\
\hline T6 & 80 & 20 & 1 \\
\hline T7 & 80 & 20 & 1.25 \\
\hline T8 & 80 & 20 & 1.5 \\
\hline
\end{tabular}




\section{E. Sensory evaluation}

The sensory evaluation of the different treatments was carried out on 50 sesame consuming panelists $(25$ women and $25 \mathrm{men}$ ) from the University of Córdoba, aged between 17 and 47 years old, by means of preference and acceptance tests. To this end, a pre-selection of the candidates was carried out, then they were specifically selected, and finally the tasters were trained according to Tamarit [21].

The preference test was conducted following the methodology defined by Ramirez-Navaset al.,[22], which consisted of asking the panelists which coded sample they preferred, in order to select one, even if they were unsure.

For its part, the acceptance test took into account the scores achieved by each treatment for each parameter evaluated (taste, odour, texture, appearance and general appearance) on a nine (9) point scale, where one (1) was "I like very much", two (2) "I like much", three (3) "I like it", four (4) "I like slightly", five (5) "I neither like nor dislike it", six (6) "I dislike slightly", seven (7) "I dislike it", eight (8) "I dislike much" and nine (9) "I dislike very much" [22].

1) Presentation of samples: The tasting of the eight treatments, randomly coded, was carried out by dividing them into two blocks. Four randomly distributed treatments were evaluated in each section, taking care that all samples had the possibility of occupying the first place the same number of times, to avoid error by sorting. The samples were delivered to the panelists in trays with a white surface which contained each treatment in individual transparent containers with a lid, with a spoon for tasting. The test was carried out in anfree-odour and illuminated space at a temperature of $25{ }^{\circ} \mathrm{C}$ and a relative humidity of $62 \%$. Together with the samples, they were given a glass of water to rinse the mouth after each tasting and an evaluation format in which they evaluated the preference and acceptance of each characteristic according to the scale in the format reported by Ramírez-Navas et al., [22].

\section{F. Statistical analysis}

The data obtained were analysed for variance and the Friedman test, the latter to compare J population averages when working with related samples, using the software Statgraphics Centurion 16.103, with a significance level of $5 \%$. In order to perform the Friedman test, once the averages of each category were obtained by treatment, five categories (taste, smell, texture, appearance and general aspect) were handled in each treatment, using the statistical software, a non-parametric variance analysis was performed.

\section{RESULTS AND DISCUSSIONS}

\section{A. Preference test}

Fig. 1 shows the percentage of panelists who preferred each of the samples, noting that $\mathrm{T} 2$ had a greater degree of preference $(22 \%)$ than the rest of the treatments, while T8 was the least preferred with a percentage of $4 \%$.

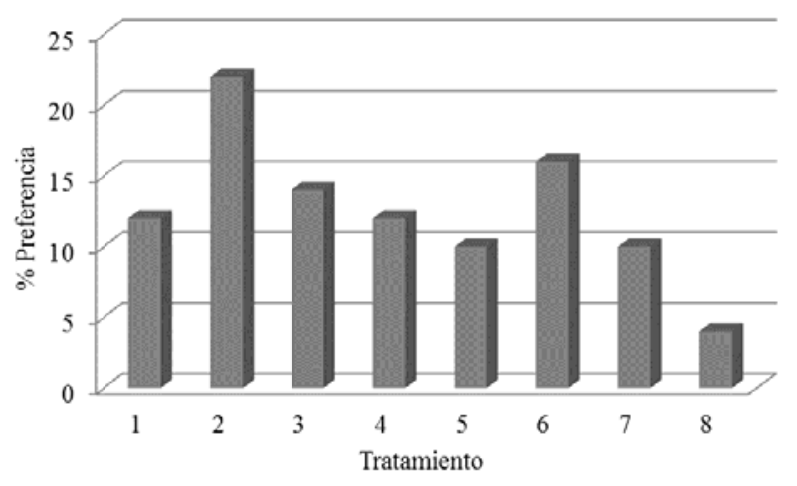

Fig. 1.Preference for sweetened sesame paste.

\section{B. Acceptance test}

Table 2 shows the summary of results obtained in the acceptability test. In Table 3, averages with a common letter are not significantly different $(\mathrm{p}>0.05)$. It was evidenced that the best treatment was $\mathrm{T} 2$, followed by $\mathrm{T} 6$. T8 showed significant differences in the parameters evaluated when compared to other treatments, and in turn had the lowest acceptance in the evaluated attributes, this could be due to the fact that in its formulation compared to T4 was the treatment that had the least amount of syrup and higher percentage of paste, even having the same plasma concentration. 
Table 2.Summary of results obtained in the acceptability test.

\begin{tabular}{|c|c|c|c|c|c|}
\hline Treatment & OverallAcceptance & Taste & Odor & Texture & Appearance \\
\hline T1 & $2.74 \pm 1.4$ & $2.78 \pm 1.7$ & $2.86 \pm 1.3$ & $2.82 \pm 1.4$ & $2.96 \pm 1.5$ \\
\hline T2 & $2.12 \pm 1.0$ & $2.18 \pm 1.1$ & $2.84 \pm 1.2$ & $2.76 \pm 1.6$ & $2.64 \pm 0.9$ \\
\hline T3 & $2.72 \pm 1.2$ & $2.84 \pm 1.4$ & $2.52 \pm 1.4$ & $2.94 \pm 1.6$ & $2.54 \pm 1.0$ \\
\hline T4 & $2.58 \pm 1.2$ & $2.58 \pm 1.6$ & $2.74 \pm 1.4$ & $2.78 \pm 1.4$ & $2.88 \pm 1.3$ \\
\hline T5 & $2.72 \pm 1.3$ & $2.78 \pm 1.5$ & $2.54 \pm 1.1$ & $2.72 \pm 1.4$ & $2.68 \pm 1.3$ \\
\hline T6 & $2.64 \pm 1.3$ & $2.96 \pm 1.8$ & $2.38 \pm 1.2$ & $2.36 \pm 1.3$ & $2.82 \pm 1.5$ \\
\hline T7 & $3.34 \pm 1.6$ & $3.56 \pm 1.8$ & $2.82 \pm 1.3$ & $2.8 \pm 1.4$ & $3.18 \pm 1.7$ \\
\hline T8 & $2.92 \pm 1.1$ & $3.26 \pm 1.4$ & $2.48 \pm 1.3$ & $3.22 \pm 1.7$ & $3.16 \pm 1.7$ \\
\hline
\end{tabular}

Table 3. Sensory acceptability of pastes $(n=5)$.

\begin{tabular}{|c|c|c|c|c|c|c|c|c|}
\hline Treatment & Sum (Ranks) & Mean (Ranks) & & & & & & \\
\hline T2 & 14.00 & 2.80 & A & & & & & \\
\hline T6 & 15.00 & 3.00 & A & B & & & & \\
\hline T5 & 17.00 & 3.40 & A & B & C & & & \\
\hline T4 & 18.00 & 3.60 & A & B & C & D & & \\
\hline T3 & 20.50 & 4.10 & A & B & C & D & E & \\
\hline T1 & 29.50 & 5.90 & & & C & D & E & F \\
\hline T7 & 31.00 & 6.20 & & & & D & E & F \\
\hline T8 & 35.00 & 7.00 & & & & & & F \\
\hline
\end{tabular}

From the results obtained, it can be inferred that acceptance and preference vary according to the percentage of plasma and syrup; that is, as the concentration of bovine plasma increases and the proportion of syrup decreases, the preference of samples declines considerably. Additionally, it is observed that $1 \%$ incorporation of plasma in the formulation of the pastes is sufficient to create a product with sensorial characteristics acceptable to the consumer, since the formulations with these quantities were the ones that obtained higher scores in both types of test (T2 and T6), being this plasma content sufficient in the formulation of the paste, since higher concentrations make it perceptible, generating consumer rejection towards the product. In contrast, Benitez et al., [23] who claimed that the inclusion of blood plasma in a flour biscuit did not affect the sensory characteristics of the product, resulting in high acceptability.Instead, Izasaet al., [24] reported that the production of salami without bovine plasma was the one that best reported the acceptability of sensory characteristics such as smell, taste and hardness, this could be due to the presence of lipidic compounds, which would affect gelification behavior, agent-surface interaction and protein concentration.

Julio et al., [18] evaluated the quality and acceptability of sausages formulated with bovine blood plasma and sesame paste, finding that the addition of blood plasma improves yield, increases protein content and reduces the fat content, without having a negative effect on acceptability.

\section{CONCLUSIONS}

The inclusion of blood plasma at 1\% may represent an improvement in the sensory quality of foodstuffs such as sesame paste. It was also evidenced that the best treatment was T2, which would serve as a starting point for the formulation of pastry products. It is concluded that the acceptance and preference of pastes varies according to the percentage of plasma and syrup, possibly due to the presence of lipidic compounds of sesame paste, which would affect the gelling behaviour.

\section{REFERENCES}

[1] D. Acevedo, P.M. Y. Montero, Y.A. Marrugo, "Caracterización reológica de pastas untuosas artesanal y tecnificada de ajonjolí (Sesamumindicum) Cultivado en Zambrano-Bolívar (Colombia)", Información Tecnológica, vol. 25, pp. 73-78, 2014.

[2] M.Rostamia, V.Farzanehb, A.Boujmehrania, M. Mohammadic, H. Bakhshabadid, "Optimizing the extraction process of sesame seed's oil using response surface method on the industrial scale", Industrial Crops and Products, vol. 58, pp. 160-165, 2014.

[3] T.Bezerra, F.A.Arruda, D.T.Duarte, N.M.Silva, M. Barbosa, K. Costa De Araújo, "Chromatography, spectroscopy and thermal analysis of oil and biodiesel of sesame (Sesamumindicum) - An alternative for the Brazilian Northeast", Industrial Crops and Products, vol. 91, no. 30, pp. 264-271, 2016. 
[4] H. Dur-Zong, C. Pei-Yi, J. I-Ming, "Daily sesame oil supplement attenuates joint pain by inhibiting muscular oxidative stress in osteoarthritis rat model", The Journal of Nutritional Biochemistry, vol. 29, pp. 36-40, 2016.

[5] J.R.Sarkisa, N.Boussetta, I.C.Tessaro, L.D. Ferreira, E. Vorobiev, "Application of pulsed electric fields and high voltage electrical discharges for oil extraction from sesame seeds", Journal of Food Engineering, vol. 153, pp. 20-27, 2015

[6] X. Wei, "Genetic discovery for oil production and quality in sesame", New Biotechnology, vol. 6, pp. 1-10, 2015.

[7] R. Bhata, K.R. Nadha, "Challenges and issues concerning mycotoxins contamination in oil seeds and their edible oils: Updates from last decade", Food Chemistry, vol. 215, no. 15, pp. 425-437, 2017.

[8] M. Kumar, M.P. Sharma, "Selection of potential oils for biodiesel production", Renewable and Sustainable Energy Reviews, vol. 56, pp. 1129-1138, 2016.

[9] F.A.Dawodu, O.O. Ayodele, T. Bolanle-Ojo, "Biodiesel production from SesamumindicumL. seed oil: An optimization study", Egyptian Journal of Petroleum, vol. 23, pp. 191-199, 2014.

[10] V.K. Shanbhag, "Oil pulling for maintaining oral hygiene - A review", Journal of Traditional and Complementary Medicine, vol. 7, no. 1, pp. 106-109, 2017.

[11] M. Al-Bachir, "Some microbial, chemical and sensorial properties of gamma irradiated sesame (SesamumindicumL.) seeds",Food Chemistry, vol. 197, (Part A), pp. 191-197, 2016.

[12] P.M. Montero, D.Acevedo, A.J. Arnedo, N.K Miranda, "Efecto de la incorporación de plasma sanguíneo y pasta de ajonjolí en la fabricación de un embutido tipo salchicha”, Información Tecnológica, vol. 26, pp. 55-64, 2015.

[13] D.F.Tirado, P.M. Montero, D. Acevedo, "Aceptabilidad sensorial y calidad microbiológica de bebidas a base de arroz y plasma bovino y porcino", Información Tecnológica, vol. 26, pp. 45-54, 2015.

[14] D.Acevedo, Y.A. Marrugo, P.M. Montero, "Evaluación de las propiedades reológicas de pastas de ajonjolí artesanal y tecnificada", Revista UDCA Actualidad y Divulgación Científica, vol. 16, pp. 245-251, 2013.

[15] B.Abu-Jdayil, K. Al-Malah, H. Asoud, "Rheological characterization of milled sesame (tehineh)". FoodHydrocolloids, vol. 16, pp. 55$61,2002$.

[16] B., Benítez, A., Archile, L., Rangel, M., Bracho, M. Hernández, E. Márquez, "Calidad nutricional y aceptabilidad de un producto formulado con carne de pollo deshuesada mecánicamente, plasma y glóbulos rojos de bovino”, ALAN, vol52, no. 3, pp. 307-312, 2002.

[17] P.M. Montero, Y.A. Marrugo, L.C. Julio, "ProteinQuality of Rice DrinksFortifiedwithBovine and PorcineBlood Plasma", Revista Facultad Nacional de Agronomía, vol. 68, pp. 7487-7496, 2015.

[18] L.C. Julio, P.M. Montero, D. Acevedo, "Calidad y aceptabilidad de chorizos formulados con plasma sanguíneo bovino y pasta de ajonjolí”, Información Tecnológica, vol. 26, pp. 25-32, 2015.

[19] A.Camacho, P.M. Montero,M. Duran,"Efecto de la adición de plasma sanguíneo de bovino en el contenido protéico, aceptabilidad y calidad microbiológica de una bebida a base de arroz", Revista Alimentos Hoy, vol. 22, no. 31, pp. 104-108, 2014.

[20] S.E. Valdés, "Hidratos de carbono. En Badui, S. Química de los alimentos. 4 ed. Ciudad de México (México): Pearson Educación, pp. 32-33, 2006.

[21] Y. Tamarit, Caracterización de la textura sensorial e instrumental del camarón de cultivo Litopenaeusvannamei en la camaronera de Tunas de Zaza. [Tesis de maestría], La Habana (Cuba): Universidad de la Habana. Instituto de Farmacia y Alimentos, 17 p. 2008.

[22] J.S.Ramírez-Navas, V. Castro, Analysis Of Acceptance And Preference Of Manjar Blanco Del Valle. Biotecnología en el Sector Agropecuario y Agroindustrial, vol. 12, no. 1, pp. 20-27,2014.

[23] B.Benítez, A.Archile, L.Rangel, K.Ferrer, Y. Barboza, E. Márquez, "Composición proximal, evaluación microbiológica y sensorial de una galleta formulada a base de harina de yuca y plasma de bovino. Interciencia, vol. 33, no. 1, pp. 61-65, 2008.

[24] R Isaza, J.M.Londoño, L.M.Ramírez, D.A.Restrepo, M.Cortes, H. Suárez, "Producción y propiedades funcionales de plasma bovino hidratado en embutido tipo salchichón”, Revista Colombiana de Ciencias Pecuarias, vol. 23, no. 2, pp. 199-206, 2010. 